UC-70

Isaued: December 1987

LA- -11162-MS

DE88 002512

\title{
Methods for Obtaining Sorption Data from Uranium-Series Disequilibria
}

\author{
David L. Finnegan \\ Ernest A. Bryant
}

DISCLAIMER

\begin{abstract}
This report was prepared as an account of work sponsored by an agency of the United States Government. Neither the United States Government nor any agency thereof, nor any of their employees, makes any warranty, express or implied, or assumes any l-gal liability or responsibility for the accuracy, completeness, or usefulness of any information, apparatus, product, or process disclosed, or represents that its use would not infringe privately owned rights. Reference herein to any specific commercial product, process, or service by trade name, trademark, manufacturer, or otherwise does not necessarily constitute or imply its endorsement, recommendation, or favoring by the United States Government or any agency thereof. The views and opinions of authors expressed herein do not necessarily state or reflect those of the United States Government or any agency thereof.
\end{abstract}

\section{MASTER}

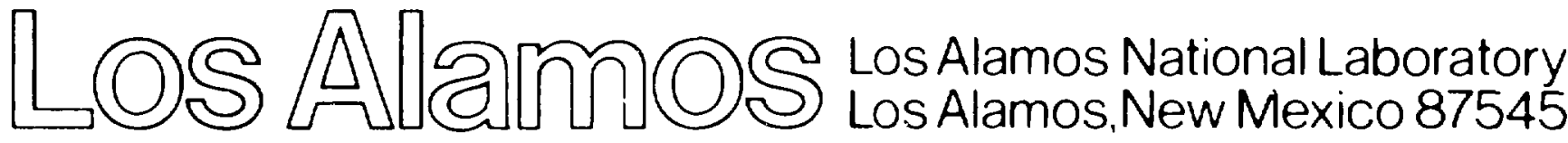




\title{
METHODS FOR OBTAINING SORPTION DATA FROM URANIUM-SERIES DISEQUILIBRIA
}

\author{
by
}

David L. Finnegan and Ernest A. Bryant

\begin{abstract}
Two possible methods have been identified for obtaining in situ retardation factors from measurements of uranium-series disequilibria at Yucca Mountain. The first method would make use of the enhanced ${ }^{234} \mathrm{U} /{ }^{238} \mathrm{U}$ ratio in groundwater to derive a signature for exchangeable uranium sorbed on the rock; the exchangeable uranium would be leached and assayed. The second method would use the ratio of ${ }^{222} \mathrm{Rn}$ to ${ }^{234} \mathrm{U}$ in solution, corrected for weathering, to infer the retardation factor for uranium. Similar methods could be applied to thorium and radium.
\end{abstract}

\section{INTRODUCTION}

Research at Yucca Mountain in Nevada, which is being studied as a potential repository for high-level nuclear waste, is coordinated under the Nevada Nuclear Waste Storage Investigations Project managed by the Nevada Operations Office of the Department of Energy. Assessment of the potential consequences of such disposal includes calculations of transportation of the various radionuclides through the surrounding geologic media both under anticipated conditions of unsatured flow $(<1 \mathrm{~mm} / \mathrm{yr})$ and under unanticipated groundwater flow conditions. Interaction of the radionuclides with the surfaces of the geologic host rock is expected to retard the rate of migration of the radionuclides relative to the flow rate of water. Such interactions, often referred to as sorption processes, are being extensively studied in laboratory experiments and may be the subject of future field experiments. Data from laboratory or field experiments suffer from a major shortcoming. The experimental time scale is constrained to very short periods relative to the thousands of years during which migration from a repository might take 
place. Geochemical processes are often very slow, especially at the moderate temperatures and pressures near the surface of the earth. The chemical species present in solution may change slowly with time; this may be important for plutonium, which tends to slowly form colloids. The sorption behavior of the slowly formed species may be different from that of the initial form, or there may be a variety of sorption sites, some of which are accessed only slowly. Thus there could be considerable difference between a radionuclide's behavior in a situation where migration is taking place over thousands of years and its behavior in a short-term experiment.

The purpose of the present report is to discuss and evaluate the prospects for obtaining useful "radionuclide retardation" data from studies of the distribution of the naturally occurring radionuclides that make up the ${ }^{238} \mathrm{U},{ }^{235} \mathrm{U}$, and ${ }^{232} \mathrm{Th}$ decay series. We will focus on the ${ }^{238} \mathrm{U}$ series in particular.

Natural uranium contains $99.3 \%{ }^{238} \mathrm{U}$, which has a half-life of $4.5 \times 10^{9} \mathrm{yr}$ and decays by alpha emission to ${ }^{234} \mathrm{Th}$. The recoil energy imparted to the ${ }^{234} \mathrm{Th}$ atom is sufficient to dislodge it from sites near the surface of a solid. The ${ }^{234} \mathrm{Th}$ decays with a 24-day half-life to the $250000-\mathrm{yr}^{234} \mathrm{U}$, passing through short-lived ${ }^{234} \mathrm{~Pa}$ on the way. The $75000-y r{ }^{230} \mathrm{Th}$ daughter of ${ }^{234} \mathrm{U}$ and its 1600 -yr daughter ${ }^{228} \mathrm{Ra}$ are both subject to the recoil effect mentioned above. A series of beta and alpha decays, beginning with the 4-day ${ }^{222} \mathrm{Rn}$ daughter of ${ }^{226} \mathrm{Ra}$, lead eventually to stable ${ }^{206} \mathrm{~Pb}$.

An initially isolated uranium source eventually will "grow in" the entire series of radioactive daughters. In the equilibrium mixture, the decay rate of each daughter will equal that of the longer lived uranium parent (secular equilibrium). Equilibrium will be established in a "closed" geologic system in a few million years. In an "open" geologic system there may be processes that will separate various members of the chain based on their individual chemical properties or environment. Similarly, the recoil caused by alpha decay can dislodge a near-surface atom and leave it in solution. Recoil can also cause localized crystal damage and result in a modified chemical environment for the recoiled atom. Because ${ }^{238} \mathrm{U}$ decays by alpha particle emission, the ${ }^{234} \mathrm{Th}$ daughter, and eventually the ${ }^{234} \mathrm{U}$ daughter, may be distributed differently in rock and water or may have a different chemical environment that makes them more susceptible to oxidation or leaching than the ${ }^{238} \mathrm{U}$ parent. As a result of the recoil and leaching processes, the isotopic composition of uranium in solution may differ from the composition in the solid. 
This isotopic fractionation of uranium isotopes was first discovered by Cherdyntsev (1955), and the mechanisms have been reviewed by Osmond and Cowart (1982). In addition, there may be chemical fractionation among the uranium daughter isotopes (protactinium, thorium, radium, radon, etc.) as a result of processes such as dissolution, precipitation, and sorption.

In crustal rocks, the average ${ }^{232} \mathrm{Th} /{ }^{238} \mathrm{U}$ ratio is about 3.8 ; the two elements behave similarly in igneous processes. The actinides are enriched, along with other incompatible elements, in late-crystallizing magmas and residual solutions such as granites and pegmatites.

The chemistry of uranium in geologic settings is dominated by its ability to exist in two oxidation states. Uranium(VI) is relatively soluble, forms a number of stable, soluble complexes as well as a number of insoluble minerals, and is the stable oxidation state in the presence of oxygen-containing groundwater. It is strongly sorbed on freshly formed iron and manganese oxides; it also is strongly co-precipitated with these and other hydrous oxides. Uranium(IV) forms strong bonds with a variety of anions and is the predominant oxidation state present in the highly insoluble, common ore mineral uraninite (uranium dioxide).

Thorium exhibits only the (IV) oxidation state and, like uranium(IV), its oxide is extremely insoluble and forms strong bonds with a variety of anions.

The chemistry of radium is very similar to that of barium, its congener. Its geologic behavior is strongly influenced by its ability to form, and be co-precipitated with, insoluble sulfates and carbonates. It also forms a number of complex ions. When radium is fractionated from its parent thorium, it is generally found in hydrothermal precipitates.

The principal mode of transport for thorium is thought to be in insoluble resistate materials as it is too insoluble to be carried in solution. Uranium is thought to be transported mainly as the oxidized uranyl species-probably as a complex ion. Insoluble radium carbonates can be mobilized by the introduction of sufficient carbon dicxide to form the more soluble bicarbonate. Overall, in the geologic environment uranium is the most mobile of the three elements and thorium is the least.

The existence in nature of the radioactive members of the uranium and thorium decay series (and their tendency to fractionate for various reasons) presents at least the possibility for in situ study of migration and sorption processes. In the following sections we first explore what has been learned about, and inferred from, the distribution of these radionuclides in geologic settings, including Yucca Mountain. We then consider what might be learned about sorption by additional studies. 


\section{MECHANISMS AFFECTING CONCENTRATION OF RADIONUCLIDES}

As a result of the study of the naturally occurring uranium and thorium decay series, a model describing the mechanisms by which the radionuclides are redistributed between solid and solution has evolved (see, for example, Dickson and Davidson, 1985). The model is intended to apply to near-surface, low-temperature geologic environments and includes the assumptions and features listed here.

1. Radionuclides occupying interior crystalline sites in a rock are not accessible for exchange with solution on a time scale of hundreds of thousands of years.

2. Radionuclides occupying surface (or very near surface) sites may be released into the solution as a direct result of the energy imparted by alpha recoil.

3. Damage to the crystal lattice caused by alpha recoil of a near-surface radionuclide may leave that atom in a more readily leachable or exchangeable form.

4. Radionuclides in solution may reversibly sorb on the surface of mineral grains or be incorporated in secondary alteration minerals; for example, in manganese and iron oxides or in opal.

5. Alpha recoil may remove radionuclides from solution or from an exchangeable surface layer by embedding the atoms in the solid matrix. Up to $50 \%$ of the recoiling surface atoms may be lost in this way. Minerals with large surface areas, such as zeolites, may be especially effective in capturing recoil products.

6. Radionuclides may be released to solution during weathering or alteration of rock minerals. For example, uranium is more readily mobilized in an oxidizing environment, possibly as a carbonate complex, and the devitrification of tuff may also result in mobilization. This effect is relatively more important for longer lived radionuclides.

7. Because radon is chemically unreactive, the concentration of ${ }^{222} \mathrm{Rn}$ in solution can be used as an indicator of the rate at which radionuclides in the ${ }^{238} \mathrm{U}$ decay series are supplied to the solution. Activity ratios (ARs) for the other members of the decay series to ${ }^{222} \mathrm{Rn}$ may be less than 1.0 as a result of adsorption, precipitation, or other loss mechanisms. 


\section{REPRESENTATIVE STUDIES OF URANIUM AND THORIUM}

SERIES

To illustrate the nature of the information obtainable by study of the uranium and thorium decay series, we present here the salient features of a series of selected papers. Because the literature is voluminous and has been reviewed earlier (Ivanovich and Harmon, 1982), we make no attempt at a comprehensive review.

\section{URANIUM MIGRATION IN AN AQUIFER}

In an introduction to their classic study of the Carrizo aquifer in Texas, Cowart and Osmond (1974) discuss the range and distribution of reported ARs for the uranium series. Reported ${ }^{234} \mathrm{U} /{ }^{238} \mathrm{U}$ ARs vary by a factor of more than 20 . Oxidizing (near-surface) waters tend to haye moderate disequilibria and higher uranium concentrations. Deeper, reducing waters tend to have lower uranium concentrations and more variable ${ }^{234} \mathrm{U} /{ }^{238} \mathrm{U}$ ARs. Whereas typical ocean water has a ratio of about 1.15 , streams are as hifh as 6 , and the ratios in sediments are low. Groundwaters exhibit ratios of 0.5 to 12. Earthquakes appear to lower the ratio, possibly by exposing fresh uranium to the solution.

The Carrizo aquifer consists of quartz sand with minor amounts of clay, shale, lignite, and pyrite. The ${ }^{14} \mathrm{C}$ age of Carrizo waters has been measured (Pearson and White, 1967). Based on extensive study, investigators believe that the recharge source is meteoric water and that the aquifer is well confined over the $100-\mathrm{km}$-long study area. From the observed uranium concentration and isotopic disequilibrium distribution along the aquifer, Cowart and Osmond infer that as water flows along the aquifer its uranium is precipitated at a "redox" boundary and that the precipitation zone is located where the uranium concentration drops abruptly from a few parts per billion to a few parts per trillion. They assume the precipitation takes place in an isotopically nonselective manner. Their observations were that the ${ }^{234} \mathrm{U} /{ }^{238} \mathrm{U}$ AR first increases and then decreases as the water passes through and beyond the apparent uraniferous zone

Cowart and Osmond developed a simple model to interpret the ${ }^{234} \mathrm{U} /{ }^{238} \mathrm{U}$ ARs in the Carrizo aquifer. Over the first few kilometers beginning at the recharge zone, uranium is being leached from the aquifer rock by oxygenated water. The ${ }^{234} \mathrm{U} /{ }^{238} \mathrm{U}$ AR of the leached uranium is 1 or less. Cowart and Osmond propose that the fairly well defined zone where the uranium concentration in solution drops precipitously is the result of an oxidation-reduction boundary. In passing through the uranium deposit, the groundwater would pick up excess ${ }^{234} \mathrm{U}$ from alpha recoil into the water, thus accounting for the high AR (5 to 9) immediately downstream. 
Further down the aquifer, beyond the precipitation zone, there is insufficient precipitated uranium to maintain the high ${ }^{234} \mathrm{U}$ concentration in the solution, so the ${ }^{234} \mathrm{U}$ decays away with its natural $0.25-\mathrm{Myr}$ half-life. However, the activity of ${ }^{234} \mathrm{U}$ drops more quickiy as a function of distance (by a factor of 20 or more) than would be piedicted from its decay constant and the velocity of the water as estimated from its apparent age and from hydrologic estimates. They attributed this apparent "rapid" decay to the fact that the downstream water never had a high AR-a situation that col: 1 hava resulted from a shift in the position of the redox boundary relative to the uranium deposit. They hypothesize that at the time when the water now downstream from the uranium deposit was passing through the redox boundary, the boundary was located downstream of the deposit. Thus mos' 6 of the excess ${ }^{234} U$ picked up in the deposit was subsequently precipitated at the redox boundary. More recently, the boundary has moved upstream until it precedes the uranium deposit.

The Cowart an Osmond hypothesis of a moving redox boundary was not wholly satisfactory, and several papers were subsequently published with alternative models (Fröríich et al., 1982, 1984; Pearson et al., 1983; and Dickson and Davidson, 1985). In the most recent paper, Dickson and Davidson present a model to explain the rapid decrease in AR with distance. By this time the aquifer had been very thoroughly studied, and they were able to include flow, sorption, and recoil effects to model the confined, chemically reducing portion of the aquifer. Their model included the assumptions discussed above in the Sec. II.

As had previous modelers, Dickson and Davidson considered sorption of uranium on the aquifer rock, a process not included in Cowart and Osmond's model. The sorption slows the average velocity of each uranium atom by the ratio of the time spent sorbed on the rock to the time spent in solution. With a lower velocity than the water, the uranium will appear to "age" more rapidly than the water as a function of distance. Thus the inclusion of sorption solved the major difficulty in the Cowart and Osmond model.

A major innovation in the Dickson and Davidson model was the inclusion of alpha recoil as a specific mechanism affecting the isotopic composition of uranium in solution. By including alpha recoil, the model explained ARs below 1.0 as well as those above 1.0; the model assumes that uranium sorbed on the rock surface can lose ${ }^{234} \mathrm{U}$ into the rock by recoil, thus providing a mechanism for reducing the $A R$ in the sorbed uranium. It is assumed that sorbed uranium is in equilibrium with uranium in solution and therefore has the same isotopic composition.

Dickson and Davidson were best able to fit the data using a $\mathrm{Kd}$ of about 65 and assuming that the supply of ${ }^{234} \mathrm{Th}$ from the solid to the water was $2 \times 10^{-5}$ (the fraction 
of total ${ }^{238} \mathrm{U}$ decays). Their model indicates that if the water velocity or age of the water can be determined independently in a well-defined system, then ${ }^{234} \mathrm{U} /{ }^{238} \mathrm{U}$ can be used to determine sorption factor (Kds).

\section{DISEQUILIBRIA IN TUFFS}

Rosholt (1980) found that in Pleistocene tuffs at Lake Tecopa, California, the ${ }^{234} \mathrm{U} /{ }^{238} \mathrm{U}$ ARs varied from 1.01 to 1.65 ; the highest values were found in zeolitized 0.6Myr-old tuff, and lower values were found in 0.7- and 2.0-Myr-old tuff. In Pliocene tuff from Keg Mountain, Utah, the ${ }^{234} \mathrm{U} /{ }^{238} \mathrm{U}$ ARs varied from 0.51 to 1.03 ; zeolitic components were observed with $50 \%$ deficiencies in ${ }^{234} \mathrm{U}$.

Rosholt proposed that daughter emplacement by alpha recoil from solution results in daughter ARs greater than 1.0 in the solid. This ${ }^{234} \mathrm{U}$ emplacement is enhanced by the large surface areas of zeolites. Daughter displacement from solids is also proposed and could result in ${ }^{234} \mathrm{U} /{ }^{238} \mathrm{U}$ being much less than 1 . In the 10-Myr-old Keg Mountain tuff, displacement predominated over emplacement, resulting in a $50 \%$ deficiency of ${ }^{234} \mathrm{U}$ in the zeolite. This deficiency was attributed to selective leaching of the displaced ${ }^{234} \mathrm{U}$ from accessible recoil sites. Rosholt also notes that ${ }^{234} \mathrm{U}$ and ${ }^{230} \mathrm{Th}$ could be used as analogues for the important nuclear waste nuclides ${ }^{233} \mathrm{U}$ and ${ }^{229} \mathrm{Th}$, respectively, because their half-lives are similar and they are isotopes of the same element with similar decay histories.

Zielinski et al. (1986) reported that in Yucca Mountain volcanic tuffs the vitrophyre contains the uranium decay series in equilibrium. The vitrophyre contains about $5 \mathrm{ppm}$ uranium and $24 \mathrm{ppm}$ thorium. He found that there is more variability in uranium distribution than in thorium and that the uranium concentration is lower (about $4 \mathrm{ppm}$ ) in moderately to densely welded devitrified tuffs. He also reported that ${ }^{226} \mathrm{Ra}$ is poorly correlated with ${ }^{230} \mathrm{Th}$ in the same tuffs. By conducting leaching experiments, he showed that a small fraction ( 0.5 to $9 \%$ ) of the total uranium is present in leachable secondary minerals (manganese-oxide, iron-oxide, and calcite). Fission-track measurements showed that local uranium concentrations occur in zircon and apatite in devitrified tuff.

Zielinski et al. attributed the observed greater variability for uranium concentration to the aqueous redistribution of uranium. The lack of correlation of radium to thorium in tuff is also interpreted as a sign of redistribution of radium. A loss of uranium during devitrification is indicated by the observation that the ratio of uranium to thorium is about $10 \%$ higher in the vitrophyre than in devitrified tuff. Zielinski et al. comment that very local redistribution can result in disequilibria in particular minerals even through the whole rock containing the minerals maintains equilibrium. The presence of small amounts 
of uranium in secondary minerals formed during devitrification shows that uranium has been redistributed and is captured in alteration products.

Zielinski et al. deduced the times at which several redistributions took place from uranium-series disequilibria. One Yucca Mountain fracture-filling calcite exhibited a ${ }^{230} \mathrm{Th}$ deficiency corresponding to a closed-system model age of $30000 \mathrm{yr}$. Such a deficiency is conclusive evidence of recent (within $\sim 30000 \mathrm{yr}$ ) redistribution of uranium or thorium (or both) but does not prove that the fracture-filing itself was precipitated as recently as $30000 \mathrm{yr}$. Other observed redistribution apparently took place much earlier-more than $400000 \mathrm{yr}$ ago. The calculated age is, of course, based on growth-decay relations among the measured isotopes (model age). The whole rock at Yucca Mountain, however, appears to have been "closed" to the uranium series, within the $10 \%$ experimental uncertainty, for several million years.

\section{GROUNDWATER DISEQUILIBRIA AT THE NEVADA TEST SITE}

In a review of groundwater data for the Nevada Test Site (NTS), Zielinski and Rosholt (1978) report that NTS groundwater contains from 0.2 to $21 \mathrm{ppb}$ of dissolved uranium. There is more variability in the uranium content of water from tuffaceous aquifers than in water from valley fill or carbonate aquifers; the highest and lowest concentrations are observed in the tuff. The uranium concentration in the tuffaceous aquifer is strongly correlated with sodium, carbonate, and dissolved solids; a similar correlation was observed in a carbonate aquifer. No strong correlation existed between uranium concentration and depth. Fairly large ${ }^{234} \mathrm{U} /{ }^{238} \mathrm{U}$ ARs of 3 to 5 were observed, and there was an inverse correlation between the ARs and dissolved uranium. Reported ${ }^{226} \mathrm{Ra} /{ }^{238} \mathrm{U}$ ARs are less than 1.7 and are all given as upper limits.

Zielinski and Rosholt (1978) believe that uranium is mobilized in NTS waters during volcanic glass dissolution and that it is transported as a uranyl carbonate complex. The inverse correlation between dissolved uranium and aqueous $A R$ indicates that the uranium is absorbed by a relatively insoluble surficial phase. Variability in uranium content of the water in the tuff is attributed to inhomogeneous flow patterns and contact with different solid phases. The high ${ }^{234} \mathrm{U} /{ }^{238} \mathrm{U}$ AR may be due to preferential oxidation and dissolution of ${ }^{234} \mathrm{U}$ or alpha recoil of ${ }^{234} \mathrm{U}$ directly into solution. Low radium concentrations in the water could be caused by the water's near saturation with $\mathrm{BaSO}_{4}$; if this material did precipitate, it would co-precipitate radium present in the solution. 


\section{DISEQUILIBRIA IN CONNECTICUT GROUNDWATER}

In a study of groundwater from five aquifers in Connecticut, Krishnaswami et al. (1982) measured the activities of ${ }^{238} \mathrm{U},{ }^{234} \mathrm{U},{ }^{234} \mathrm{Th},{ }^{226} \mathrm{Ra},{ }^{222} \mathrm{Rn},{ }^{232} \mathrm{Th},{ }^{228} \mathrm{Ra},{ }^{228} \mathrm{Th}$, and ${ }^{224} \mathrm{Ra}$. They found that ${ }^{222} \mathrm{Rn}$ had 3 to 4 orders of magnitude greater activity than the other members of either decay chain. They also observed ${ }^{234} \mathrm{U}$ activities 1.1 to 5.1 times those of the ${ }^{238} \mathrm{U}$ precursor.

From their measured data, Krishnaswami et al. were able to derive in situ adsorptiondesorption rate constants and retardation factors for radium. They found that for the 5.8yr ${ }^{228} \mathrm{Ra}$ and the 3.7 -day ${ }^{224} \mathrm{Ra}$ in Connecticut groundwater, the rate of sorption is much greater than the rate of desorption and both are greater than the decay rate of ${ }^{228} \mathrm{Ra}$. A similar treatment of ${ }^{234} \mathrm{Th}$ and ${ }^{228} \mathrm{Th}$ data gave anomalous values for the rate constants; however, the authors were able to show that thorium, as well as radium, adsorbs on a time scale of minutes.

In arriving at these conclusions, Krishnaswami et al. developed a mathematical model relating the ratio of radium activity to radon activity:

$$
A R(R a / R n)=\left(k_{2}+\lambda\right) /\left(k_{1}+k_{2}+\lambda\right),
$$

where $k_{1}$ and $k_{2}$ are the sorption and desorption rate constants for radium and $\lambda$ is the decay constant for the particular radium isotope. This equation was derived by combining two equations describing the dynamic equilibrium between solution and solid with an added term for supplying the decay series to the solution by alpha recoil. It is assumed that the added term can be determined by measuring ${ }^{222} \mathrm{Rn}$ in solution. The AR must be corrected for the difference in the abundance of uranium and thorium parents in the rock because radium and radon are members of different decay series. Using simultaneous graphical solutions for the two equations (one for ${ }^{224} \mathrm{Ra}$ and one for ${ }^{228} \mathrm{Ra}$ ), they were able to obtain values for both $k_{1}$ and $k_{2}$. The retardation factor is, of course, just the inverse of the AR. Note that because the decay constant appears in the above equation, the AR will be a function of the half-life of the sorbing isotope; that is, decay competes with sorption.

Retardation factors derived from ARs for radium and thorium ranged from 4500 to 200000 . (From a comparison of uranium ratios to those for radium and thorium, one can infer that the uranium retardation factors must be very approximately an order of magnitude smaller, but the authors did not include any estimates for the uranium. See Appendix A.) 


\section{PROSPECTIVE MEASUREMENTS FOR YUCC MOUNTAIN}

A considerable amount of data for uranium and thorium series already exists for Yucca Mountain. These data have been interpreted in terms of evidence for migration, alteration, etc. We are not, however, aware of any derivation of sorption coefficients or retardation factors from Yucca Mountain data. To be useful in repository safety analyses, sorption coefficients must be scientifically defensible. Although sorption coefficients have been derived from data collected in other geologic settings and the methods used have been quite imaginative, the methods probably cannot be considered scientifically acceptable. Thus, any future work should include tests to validate the models leading to the sorption coefficients.

By following the methods employed by Krishnaswami et al. in their work with Connecticut groundwater, it may be possible to determine sorption and desorption rates for the short-lived radium and thorium isotopes and, from that data, to deduce sorption factors. Such measurements would not be justified, however, because the same short-timescale measurements could more easily be made in laboratory experiments using tuffs of Yucca Mountain. That is, by focusing on short-lived isotopes, one does not address the important question about the effect of geologic time on the sorption processes. To be useful, sorption data not only must be scientifically defensible, it also must pertain to long-time-scale sorption processes that cannot be duplicated in the laboratory.

Nevertheless, it may be possible to derive useful sorption information from studies of the uranium and thorium series at Yucca Mountain. In the following sections, we consider two possibilities for the uranium series.

\section{LEACHING EXCHANGEABLE URANIUM OR THORIUM}

When determining a meaningful uranium sorption factor from natural uranium distribution, the major problem is that most of the uranium in the rock is not exchangeable with uranium in solution and thus does not participate in the sorption equilibrium. By exchangeable, we mean that atoms of uranium are taking part in a continuing two-way transfer process (such as ion exchange) so that each atom spends some time sorbed on the rock and some time in solution. However, the ${ }^{234} \mathrm{U} /{ }^{238} \mathrm{U}$ disequilibrium provides the basis, at least in principle, for a unique determination of the exchangeable uranium in the rock. A necessary, basic assumption is that only the exchangeable uranium in the rock would have the same decay-chain-disequilibrium isotopic composition as uranium in solution.

Given that the above assumption is correct, one need only devise a scheme for preferentially leaching or dissolving the exchangeable uranium from the rock. A series of leachings would be developed to remove the exchangeable uranium more or less completely. 
Some portion of the nonexchangeable uranium would probably be leached along with the exchangeable uranium. A correction for the nonexchangeable portion can be calculated by determining how much uranium of normal isotopic composition would have to be mixed with the dissolved exchangeable uranium to produce the observed isotopic ratio, assuming that, as indicated above, the exchangeable uranium has a unifc: $m$ isotopic composition in solution and solid.

This approach is similar in concept to the leaching procedure developed by Zielinski et $u l$. (1986) to quantify the uranium in secondary manganese and iron oxides, but it has a different target. In the present instance, one would first measure the ${ }^{234} \mathrm{U} /{ }^{238} \mathrm{U}$ ratio in the water associated with a volume of rock. Then one would undertake a series of (possibly consecutively more aggressive) leachings to remove uranium from the rock. The uranium in eact leach would be isotopically assayed and quantified. Then a correction would be applied to the measured uranium in each leach solution to account for any normal uranium dissolved along with the isotopically unique exchangeable uranium.

There are potential problems with this approach. If most of the exchangeable uranium is sorbed on the rork surface at any given instant, then up to half of the newly formed ${ }^{234} U$ might be embedded in nonexchangeable sites by alpha recoil. If the rock gained enough ${ }^{234} \mathrm{U}$ by alpha-recoil to make a portion of the nonexchangeable uranium match the solution isotopically, and subsequently it was leached, then the correction for nonexchangeable uranium could be in error. Similarly, the surface layers of rock may be somewhat depleted in ${ }^{234} \mathrm{U}$ as a result of recoil loss from the decay of nonexchangeable ${ }^{238} \mathrm{U}$. These effects are likely to be small and are in opposite directions. The mechanisms involved have been discussed in some detail by Dickson and Davidson (1985) and Krishnaswami et al. (1982). Krishnaswami et al. point out that the rate at which longer lived isotopes, for example, ${ }^{234} \mathrm{U}$, are supplied to solution may be dominated by weathering. If this is so, then their method for determining sorption and desorption rates as a way of deducing sorption rate constants is not easily applicable; that is, one would need accurate estimates of the rate of weathering to incorporate in the supply term. Such a limitation does not appear to apply to the proposed method. However, careful consideration must be given to the effects mentioned and what they imply about the measurement of exchangeable uranium.

The problem of determining the thorium sorption factor can be approached in a manner similar to that for uranium. If both ${ }^{230} \mathrm{Th}$ and ${ }^{232} \mathrm{Th}$ can be measured in solution and if the ${ }^{230} \mathrm{Th} /{ }^{232} \mathrm{Th}$ ratio in solution is greater than that in the rock, then one might be able to apply a leaching method to determine the amount of exchangeable ${ }^{230} \mathrm{Th}$ on the rock, making corrections for leaching of nonexchangeable thorium that are based on 
the difference between isotope ratios for solution and leachate. Because thorium is very insoluble, it may be very difficult to leach a measurable amount of thorium from the rock.

We have been unable to devise a leaching scheme that would permit identification of exchangeable radium in the leachate.

\section{USING ${ }^{222}$ Rn WITH WEATHERING CORRECTIONS}

Krishnaswami et al. measured ${ }^{222} \mathrm{Rn}$ as an indicator of the total supply of recoil atoms to the solution. After corrections were made for recoil losses from solution and from adsorbed surface layers, radon was used as the basis fur calculating sorption factors for short-lived radium and thorium isotopes. They did not apply the method to the longer lived isotopes because they estimated that, as mertioned above, weathering was a significant, but unquantified, source of uranium in solution. It should be possible, however, for systems exhibiting significan $\hat{\imath}$ isotopic disequilibria-and therefore a relatively small fraction of weathered uranium-to correct for the weathering effect by using the observed isotopic composition of uranium in solution. To a first approximation, the weathered uranium should be normal, or possibly very slightly depleted, in ${ }^{234} \mathrm{U}$. In this approach, one would use ${ }^{222} \mathrm{Rn}$ to estimate the total ${ }^{234} \mathrm{U}$ recoiled into solution and use the ${ }^{234} \mathrm{U}$ plus ${ }^{238} \mathrm{U}$ data to establish the amount remaining in solution. It would then be assumed that the difference repres:nts sorbed uranium.

For thorium, as for uranium, $: n$.rnative is to use the ${ }^{222} \mathrm{Rn}$ as a measure of the source of ${ }^{230} \mathrm{Th}$ and to correct for the eathering source by using data for ${ }^{232} \mathrm{Th}$ in solution. Because these isotopes are in different chains, one must make additional assumptions about supply by recoil, and one must know something about the value and uniformity of the uranium/thorium ratio in the rock.

For radium, comparison of the ${ }^{226} \mathrm{Ra}$ activity with its daughter ${ }^{222} \mathrm{Rn}$ appears to be the most direct way of obtaining a sorption factor. There is no direct way to correct for the weathering source. However, a conservative correction (an over-correction leading to an underestimated retardation factor) could be based on the total amount of weathered uranium. If the chemistry of uranium and radium are compared, it seems that the weathered uranium should be roughly equivalent to-or possibly somewhat larger thanthe total weathered radium.

\section{CONCLUSIONS}

At this time, there is no proven, scientifically deferisible method for applying uranium series disequilibria to Yucca Mountain to determine the retardation of naturally occurring radioactive elements in groundwater. Two potentially useful methods have been suggested, 
but they must be developed and demonstrated before they will be scientifically defensible. Assumptions and potential problems have been discussed aboye, and applicable analytical techniques are discussed in Appendix B. The assumptions are intuitively reasonable, but their validity must be demonstrated by consistent results in a number of applications. An extensive development program would be required tc achieve a scientifically defensible method.

\section{References and Bibliography}

In the following list, entries marked with an asterisk are those referenced in the text.

Andrews, J. N., I. S. Giles, R. L. F. Kay, D. J. Lee, J. K. Osmond, J. B. Barker, and J. Gale, "Radioelements, Radiogenic Helium and Age Relationships for Groundwaters From the Granites at Stripa, Sweden," Geochim. Cosmochim. Acta 46, 1533-1543 (1982).

Andrews, J.N., and R.L.F. Kay, ${ }^{{ }^{234}} \mathrm{U} /{ }^{233} \mathrm{U}$ Activity Ratios in Groundwaters from a Jurassic Limestone Aquifer in England," Earth Planet. Sci. Lett. 57, 139-151 (1982).

Asikainen, Matt, "State of Disequilibrium Between ${ }^{238} \mathrm{U},{ }^{234} \mathrm{U},{ }^{226} \mathrm{Ra}$ and ${ }^{222} \mathrm{Rn}$ in Groundwater and Bedrock," Geochim. Cosmochim. Acta 45, 201-206 (1981).

Barr, G. E., S. J. Lambert, and J. A. Carter, "Uranium Isotope Equilibrium in Groundwaters of Southeastern New Mexico," in Isotope Hydrology, Vol. 2 (International Atomic Energy Agency, Vienna, 1978), pp. 645-660.

Benson, L. V., and P. W. McKinley, "Chemical Composition of Ground Water in the Yucca Mountain Area, Nevada, 1971-1974," US Geological Survey open file report USGSOFR-85-484 (1984).

Bhat, S. G., S. Krishnaswami, D. Lal, Rama, and W. S. Moore, ${ }^{4234} \mathrm{Th} /{ }^{238} \mathrm{U}$ Ratios in the Ocrans," Earth Planet. Sci. Lett. 5, 483-491 (1969).

Chalov, P. I., and K. I. Merkulova, "Comparative Rates of Oxidation of ${ }^{234} \mathrm{U}$ and ${ }^{238} \mathrm{U}$ Atoms in Certain Minerals," Dokl. Acad, Nauk. SSSR, Proc. Earth Sci. Sect. 167, 146 (1966).

Chalov, P. I., T. V. Tuzova, and Y. A. Musin, "The ${ }^{234} \mathrm{U} /{ }^{238}$ U Ratio in Natural Waters and Its Use in Geochronolog:" Geochim. Int. 3, 402-408 (1964).

* Cherdyntsev, V.V., P.I.Cha!ov, G.Z. Khaidarov, "Transactions of the Third Session of the Committee for Determination of Absolute Ages of Geologic Formations," Izv. Akad. Nauk. SSSR, 175 (1955).

Claassen, H. C., "Water Quality and Physical Characteristics of Nevada Test Site WaterSupply Wells," US Geological Survey report USGS-474-158 (1973). 
* Cowart, J. B., anc J. K. Osmond, ${ }^{4234} \mathrm{U}$ and ${ }^{238} \mathrm{U}$ in the Carrizo Aquifer of South Texas, ${ }^{n}$ in Isotope Techniques in Groundwater Hydrology, Vol. 2 (International Atomic Energy Agency, Vienna, 1974), pp. 131-149.

* Cowart, J. B., M. I. Kaufman, and J. K. Osmond, "Uranium-Isotope Variations in Groundwaters of the Floridan Aquifer and Boulder Zone of South Texas," J. Hydrol. 36, 161-172 (1978).

* Dickson, B. L., and M. R. Davidson, "Interpretation of ${ }^{234} \mathrm{U} /{ }^{238} \mathrm{U}$ Activity Ratios in Groundwater," Chem. Geol. 58, 83-88 (1985).

Dickson, B. L., R. L. Meakins, and C. J. Bland, "Evaluation of Radioactive Anomalies Using Radium Isotopes in Groundwaters," J. Geochem. Explor. 19, 195-205 (1983).

Fleischer, R. L., "Alpha Recoil Damage and Solution Effects in Minerals: Uranium Disequilibrium and Radon Release," Geochim. Cosmochim. Acta 46, 2191-2201 (1982).

Fleischer, R. L., "Theory of Alpha-Recoil Effects on Radon Release and Isotopic Disequilibration," Geochim. Cosmochim. Acta 47, 779-784 (1983).

Fleischer, R. L., "Isotopic Disequilibrium of Uranium: Alpha-Recoil Damage and Preferential Solution Effects," Science 207, 979 (1980).

Fleischer, R. L., and A. Delaney, "Determination of Suspended and Dissolved Uranium in Water," Anal. Chem. 48, 642-645 (1976).

Fleischer, R. L., and O. G. Raabe, "Recoiling Alpha-Emitting Nuclei. Mechanisms for Uranium-Series Disequilibrium," Geochim. Cosmochim. Acta 42, 973-978 (1978).

* Fröhlich, K., R. Gellerman, and D. Herbert, "Uranium Isotopes in a Sandstone Aquifer: Interpretation of Data and Implications for Groundwater Dating," in Isotope Hydrology, Vol. 1 (International Atomic Energy Agency, Vienna, 1984), pp. 447-466.

* Fröhlich, K., R. Gellerman, and K. Runge, "On the Migration of Uranium Isotopes in Sandstone Aquifers," in Environmental Migration of Long-Lived Isotopes, Vol. 1 (International Atomic Energy Agency, Vienna, 1982), pp. 373-382.

Gasgoyne, M., and H. P. Schwartz, "Radionuclide Migration Over Recent Geologic Time in a Granitic Pluton," Chem. Geol. 59, 75-85 (1986).

Hansen, R. O., and P. R. Stout, "Isotopic Distribution of Uranium and Thorium in Soils," Soil Sci. 105, 44-50 (1968).

Hussain, N., and S. Krishnaswami, "U-238 Series Radioactive Disequilibrium in Groundwaters: Implications to the Origins for Excess U-234 and Fate of Reactive Pollutants," Geochim. Cosmochim. Acta 44, 1287-1291 (1980).

* Ivarovich, M., and R. S. Harmon, Uranium Series Disequilibrium: Applications to Eivironmental Problems (Clarendon Press, Oxford, 1982). 
Kaufman, M. I., H. S Rydell, and J. K. Osmond, ${ }^{234} \mathrm{U} /{ }^{238} \mathrm{U}$ Disequilibrium as an Aid to Hydrologic Study of the Florida Aquifer," J. Hydrol. 9, 374-386 (1969).

Kazachevskii, I. V., V. V. Cherdyntsev, E. A. Kuz'mina, L. D. Sulerzhitsk, V. F. Mochalova, and T. N. Kyuregyan, "Isotope Composition of Uranium in the Supergene Zone and in Volcanic Products," Geochem. Int. 1, 1068 (1964).

Kigoshi, K., "Alpha Recoil ${ }^{234} \mathrm{Th}$ : Dissolution into Water and ${ }^{234} \mathrm{U} /{ }^{238} \mathrm{U}$ Disequilibrium Nature," Science 173, 47-48 (1971).

* King, P. T., J. Michel, and W. S. Moore, "Groundwater Geochemistry of ${ }^{228} \mathrm{Ra},{ }^{226} \mathrm{Ra}$, and ${ }^{222} \mathrm{Rn}, "$ Geochem. Cosmochim. Acta 46, 1173-1182 (1982).

Kraemer, T. F., ${ }^{4234} \mathrm{U}$ and ${ }^{238} \mathrm{U}$ Concentrations in Brine from Geopressurized Aquifers of the Northern Sulf of Mexico," Earth Planet. Sc8. Lett. 56, 210-216 (1981).

Krishnaswami, S., and M. M. Sarin, "Procedure for the Simultaneous Determination of Th, Pu, Ra Isotopes ${ }^{210} \mathrm{~Pb},{ }^{55} \mathrm{Fe},{ }^{32} \mathrm{Si}$, and ${ }^{14} \mathrm{C}$ in Marine Suspended Phases," Anal. Chim. Acta 83, 143-156 (1976).

* Krishnaswami, S., W.C. Graustein, K.K. Turekian, and J. F. Dowd, "Radium, Thorium, and Radioactive Lead Isotopes in Groundwaters: Applications to the In Situ Determination of Adsorption-Desorption Rate," Water Resour. J. 18, 1633-1675 (1982).

Kronfeld, J., "Uranium Deposition and ${ }^{234} \mathrm{Th}$ Alpha-Recoil: An Explanation for Extreme," Earth Planet. Sci. Lett. 21, 327-330 (1974).

Kronfeld, J., and J. A. S. Adams, "Hydrologic Investigations of the Groundwaters of Central Texas Using ${ }^{234} \mathrm{U} /{ }^{238} \mathrm{U}$ Disequilibrium," J. Hydrol. 22, 77-88 (1974).

Kronfeld, J., E., Gradsztajn, H. W. Muller, J. Radin, A. Yaniv, and R. Zach, "Excess ${ }^{234} \mathrm{U}$ : An Aging Effect in Confined Waters," Earth Planet. Sci. Lett. 27, 342 (1975).

Langmuir, D., "Uranium Solution-Mineral Equilibria at Low Temperatures with Applications to Sedimentary Ore Deposits," Geochim. Cosmochim. Acta 42, 547-570 (1978).

* Langmuir, D., and J. S. Herman, "The Mobility of Thorium in Natural Waters at Low Temperature," Geochim. Coshmochim. Acta 44, 1753-1766 (1980).

Lenda, A., and A. Zuber, "Tracer Dispersion in Groundwater Experiments," in Isotope Hydrology, Vol. 1 (International Atomic Energy Agency, Vienna, 1970), pp. 619-637.

* Lally, A. E., "Chemical Procedures in Uranium Series Disequilibrium," in Uranium Series Disequilibrium: Applications to Environmental Problems, M. Ivanovich and R. S. Harmon, Eds. (Clarendon Press, Oxford, 1982), pp. 79-106.

Megumi, K., "Radioactive Disequilibrium of Uranium and Actinium Series Nuclides in Soil," J. Geophys. Res. 84, 3677-3682 (1979). 
Moore, W. S., "Amazon and Mississippi River Concentrations of Uranium, Thorium, and Radium Isotopes," Earth Planet. Sci. Lett. 2, 231 (1967).

Neretnieks, Ivars, "Diffusion in Rock Matrix: An Importnat Factor in Radionuclide Retardation?" J. Geophys. Res. 85, 4379-4397 (1980).

* Osmond, J. K., and J. B. Cowart, "Natural Uranium and Thorium Series Disequilibrium: New Approaches to Geochemical Problems," Nucl. Sci. Appl. 1, 303-352 (1982).

Osmond, J. K., and J. B. Cowart, "Uranium-Series Disequilibrium in Groundwater and Core Composite Samples from the San Juan Basin and Copper Mountain Research Sites," US Department of E lergy, Grand Junction, Colorado, Bendix Field Engin. Corp. report (1981).

Osmond, J. K., and J. B. Cowart, "The Thecry and Use of Natural Uranium Isotopic Variations in Hydrology," At. Energy Rev. 14, 621-679 (1976).

Osmond, J. K., H. S. Rudell, and M. I. Kaufman, "Uranium Disequilibrium in Groundwater: An Isotope Dilution Approach in Hydrologic Investigations," Science 162, 997-999 (1968).

Pakalns, P., and L. E. Ismay, "The Effects of Anions on the Fluorimetric Determination of Uranium After Extraction from Calcium Nitrate Salting Out Solution, Micro Chim. Acta 1, 297-306 (1976).

* Pearson, F. J., C.J. Noronha, and R. W. Andrews, "Mathematical Modeling of the Distribution of Natural ${ }^{14} \mathrm{C},{ }^{234} \mathrm{U}$, and ${ }^{238} \mathrm{U}$ in a Regional Groundwater System," Radiocarbon 25, 291-300 (1983).

* Pearson, F. J., and D. E. White, "Carbon 14 Ages and Flow Rates of Water in Carrizo Sand, Atascosa County, Texas," Water Resour. Res. 3, 251-260 (1967).

Rosholt, J. N., "Isotope Dilution Analyses of Uranium and Thorium in Geologic Samples Using ${ }^{236} \mathrm{U}$ and ${ }^{229} \mathrm{Th},{ }^{n}$ Nucl. Instrum. Methods 223, 572-576 (1984).

Rosholt, J. N., "Isotopic Composition of Uranium and Thorium in Crystalline Rocks," J. Geophys. Res. 88, B9, 7315-7330 (1983).

* Rosholt, J. N., "Uranium and Thorium Disequilibrium in Zeolitically Altered Rock," Nucl. Technol. 51, 143-146 (1980).

Rosholt, J. N., "Quantitative Radiochemical Methods for Determination of the Sources of Natural Radioactivity;" Anal. Chem. 29, 1398-1408 (1957).

Rosholt, J. N., C. A. Bush, W. J. Carr, D. L. Hoover, W. C. Swadley, and J. R. Dooley, Jr., "Uranium Trend Dating of Quarternary Deposits in the Nevada Test Site Area, Nevada and California," US Geological Survey open file report USGS-OFR-85-540 (1985). 
Rosholt, J. N., A. P. Butler, E. L. Garner, and W. R. Shields, "Isotopic Fractionation of Uranium in Sandstone, Powder River Basin, Wyoming and Slick Rock District, Colorado," Econ. Geol. 80, 199 (1965).

Rosholt, J. N., B. R. Doe, and M. Tatsumoto, "Evolution of the Isotopic Composition of Uranium and Thorium in Soil Profiles," Geol. Soc. Am. Bull. 77, 987 (1966).

Rosholt, J. N., M. Tatsumoto, and J. R. Dooley, "Radioactive Disequilibrium Studies in Sandstone, Powder River Basin, Wyoming and Slick Rock District, Colorado," Econ. Geol. 60, 477 (1965).

Rosholt, J. N., W. R. Shields, and E. L. Garner, "Isotopic Fractionation of Uranium in Sandstone," Science 139, 224-226 (1963).

Schwarcz, H. P., M. Gascoyne, and D. C. Ford, "Uranium Series Disequilibrium Studies of Granitic Rocks," Chem. Geol. 36, 87-102 (1982).

Shirvington, P. J., "Fixation of Radionuciides in the ${ }^{238} \mathrm{U}$ Series in the Vicinity of Mineralixed Zones, 1. The Ausatom U Prospect, North Territory, Australia," Geochim. Cosmochim. Acta. 47, 403-412 (1983).

Sill, C. W., and R. L. Williams, "Radiochemical Determination of Uranium and Transuranium Elements in Process Solutions and Environmental Samples," Anal. Chem. 41, 1624-1632 (1969).

Smeillie, J. A. T., "Radioactive Disequilibria in Mineralized Drill Core Samples from the Björklund Uranium Occurrence, Northern Sweden," SVENSK Karnbransle-forsorjning technical report 82-15, (1982).

Smeillie, J. A. T., B. Mcȟenzie, and R. D. Scott, "An Analogue Validation Study of Natural Radionuclide Migration in Crystalline Rocks Using Uranium Series Disequilibrium Studies," in Scientific Basis of Nuclear Waste Management, Vol. 1 (International Atomic Energy Agency, Vienna, 1986), pp. 91-98.

Smeillie, J. A. T., and J. N. Rosholt, "Radioactive Disequilibria in Mineralized Fracture Samples fiom Two Uranium Occurrences in Northern Sweden," Lithos 17, 215-225 (1984).

Szabo, B.J., and P.A. O'Malley, "Uranium-Series Dating of Secondary Carbonate and Silica Precipitates Relating to Fault Movement in the Nevada Test Site Region of Caliche," US Geological Survey open file report USGS-OFR-85-47 (1985).

Szabo, B.J., and T.K. Kyser, "Uranium and Thorium Isotopic Analyses and UraniumS'eries Ages of Calcite and Opal, and Stable Isotopic Compositions of Calcite from Drill C'ores," US Geological Survey open file report USGS-OFR-85-224 (1985).

Thurber, D., "Anomalous ${ }^{234} \mathrm{U} /{ }^{238} \mathrm{U}$ in Nature," J. Geophys. Res. 67, 4518-4520 (1962).

Wahlgren, M. A., and K. A. Orlandini, "Comparison of the Behavior of Plutonium, Thorium, and Uranium in Selected North American Lakes," in Environmental Migration 
of Long-Lived Isotopes, Vol. 1 (International Atomic Energy Agency, Vienna, 1982), pp. 757-774.

Zielinski, R. A., D. A. Lindsey, and J. N. Rosholt, "The Distribution and Mobility of Uranium in Glassy and Zeolitized Tuff, Keg Mountain Area, Utah, USA," Chem. Geol. 29, 139 (1980).

Zielinski, R. A., Z. E. Peterman, J. S. Stuckless, J. N. Rosholt, and I. Szabo, "The Chemical and Isotopic Record of Rock-Water Interaction in the Sherman Granite, Wyoming and Colorado," Contrib. Mineral. Petrol. 78, 209-219 (1981).

* Zielinski, R.A., and J.N. Rosholt, "Uranium in Waters and Aquifer Rocks at the Nevada Test Site, Nye IJevada," US Geol. Surv. J. Res. 6, 489-498 (1978).

* Zielinski, R.A., C.A. Bush, R. W. Spengler, and B.J. Szabo, "Rock-Water Interaction in Ash-Flow Tuffs (Yucca Mountain, Nevada, USA) - The Record from Uranium Studies," Uranium 2, 361-386 (1986). 


\section{APPENDIX A \\ SAMPLE RETARDATION-FACTOR CALCULATIONS}

Data available in the paper by Krishnaswami et al. can be used to estimate retardation factors for long-lived uranium, thorium, and radium isotopes by sample retardation calculations. They report data for ${ }^{234} \mathrm{U},{ }^{228} \mathrm{Th}$, and ${ }^{226} \mathrm{Ra}$, which we have interpreted to obtain very approximate values for retardation factors. It was assumed that ${ }^{222} \mathrm{Rn}$ was equivalent to the total recoil atoms supplied to solution and that weathered uranium was equal to ${ }^{238} U$. So, for example, the formula used for uranium was $R f={ }^{222} R n /\left({ }^{234} U_{-}{ }^{238} U\right)$. Results for these calculations appear in Table A-I below. Two of the samples were chosen because of relatively high values for the ${ }^{234} \mathrm{U} /{ }^{238} \mathrm{U}$ disequilibria, which should indicate that weathering has contributed relatively little to the total ${ }^{23.4} \mathrm{U}$. Sample GW5 was chosen to provide a second point for ${ }^{228} \mathrm{Th}$.

Although there is a considerable body of uranium series data for the Nevada Test Site, there is not sufficient data to permit the kind of interpretation proposed in this report. The fact that ${ }^{234} \mathrm{U} /{ }^{238} \mathrm{U}$ ratios up to 5.0 have been ohserved in water from Well J-12 near Yucca Mountain (Zielinski and Roshot, 1978) suggests that it may be possible to apply the proposed methods at Yucca Mountain itself.

\section{TABLE A-I}

\begin{tabular}{|c|c|c|c|c|c|c|c|c|}
\hline \multirow[b]{2}{*}{ Sample } & \multirow[b]{2}{*}{${ }^{234} \mathrm{U} /{ }^{238} \mathrm{U}$} & \multirow[b]{2}{*}{${ }^{238} \mathrm{U}$} & \multirow[b]{2}{*}{${ }^{228} \mathrm{Th}$} & \multirow[b]{2}{*}{${ }^{226} \mathrm{Ra}$} & \multirow[b]{2}{*}{${ }^{222} \mathrm{Rn}$} & \multicolumn{3}{|c|}{ Approximate $\mathrm{Rf}^{a}$} \\
\hline & & & & & & $\mathrm{U}$ & Th & $\mathbf{R a}$ \\
\hline GW5 & 1.15 & - & 4.3 & - & $1.16 \times 10^{7}$ & - & $5 \times 10^{8}$ & - \\
\hline GW6 & 4.66 & 490 & 7.4 & 308 & $1.18 \times 10^{6}$ & $7 \times 10^{2}$ & $3 \times 10^{6}$ & $4 \times 10^{3}$ \\
\hline GW9 & 5.09 & 520 & - & 214 & $1.09 \times 10^{6}$ & $5 \times 10^{2}$ & - & $1 \times 10^{4}$ \\
\hline
\end{tabular}

a Approximate values for retardation factors derived from data for long-lived isotopes reported by Krishnaswami et al. (1982) for Connecticut groundwater. Data are given as activity $\left(\mathrm{dpm} / 10^{3} \ell\right)$. Water samples are from wells in arkosic rocks of Triassic-Jurassic age. 


\section{APPENDIX B}

\section{POSSIBLE ANALYTICAL TECHNIQUES FOR DETERMINATION OF URANIUM, THORIUM, AND RADIUM}

\section{ANALYTICAL TECHNIQUES}

In this section we discuss the two techniques that can be applied to the determination of uranium, thorium, radium, and radon isotopes: mass spectroscopy and alpha spectroscopy.

Most procedures for preparing samples for analysis are similar in that they include the following steps: (1) preconcentration or extraction, (2) separation, and (3) source preparation. Tracers, or spikes, for each element are usually added to determine the chemical yield for the procedure. Procedures for these steps are reviewed in Lally (1980).

\section{ALPHA SPECTROSCOPY}

Alpha spectroscopy has been widely used as an analytical tool for uranium-series disequilibria stıdies. The most often measured isotopes are ${ }^{234} \mathrm{U}$ and ${ }^{238} \mathrm{U}$. The initial volume of water from which the uranium is extracted ranges from 1 to $100 \ell$, depending on the elemental concentrations present. Uranium concentration down to $0.003 \mathrm{ppb}$ $(0.001 \mathrm{pCi} / \ell)$ have been measured using a $20-\ell$ sample and a week of counting (Cowart et al., 1978). The concentrations at Yucca Mountain range from 0.2 to $12 \mathrm{ppb}(0.07$ to $4 \mathrm{pCi} / \ell$ ), so a few liters of water would be required when this method is used to measure the most dilute uranium solutions.

Judging from the paucity of data, measurement of the thorium isotopes in groundwater is more difficult than measurement of uranium. There are few data for concentrations of thorium in water and there are no such data for Yucca Mountain. Langmuir and Herman (1980) report that in fresh water thorium concentration ranges from 0.01 to $1.0 \mathrm{ppb}(0.001$ to $0.1 \mathrm{pCi} / \ell)$; however, in seawater the concentration is about $0.00064 \mathrm{ppb}$. The bulk of the thorium mass is ${ }^{232} \mathrm{Th}$; the activity ratio for ${ }^{230} \mathrm{Th}$ is about 0.8 , which corresponds to a concentration ratio of approximately $5 \times 10^{-6}$. If Yucca Mountain water does contain thorium at the reported "fresh water" concentrations, then it should be possible to measure it by alpha spectroscopy. Large samples and long counting times would be required. If the concentrations are closer to the reported "seawater" concentration, or if the very approximate thorium retardation factors estimated from Krishnaswami et al. are correct, ther: alpha spectroscopy cannot be used. 
Where there is sufficient activity, radium and radon are easily measured by alpha counting. The ${ }^{226} \mathrm{Ra}$ is usually determined by ingrowth of ${ }^{222} \mathrm{Rn}$ but can also be determined by direct alpha counting. Values for ${ }^{226} \mathrm{Ra}$ as low as $0.02 \mathrm{ppb}(0.02 \mathrm{pCi} / \ell)$ have been determined in groundwater (King et al., 1982). Yucca Mountain water concentrations range from $<0.1$ to $0.2 \mathrm{ppb}$. The ${ }^{222} \mathrm{Rn}$ usually has a much higher activity in groundwater, by several orders of magnitude, than any of the other uranium daughters do. Therefore, we expect there should be no problem in measuring its concentration in a liter of Yucca Mountain groundwater.

\section{MASS SPECTROSCOPY}

Mass spectroscopy has not been as extensively used as alpha spectroscopy for uraniumseries measurements, but it has the potential for providing a sensitive and accurate measure of uranium and thorium isotopes in small samples. For example, to measure the ${ }^{234} \mathrm{U} /{ }^{238} \mathrm{U}$ ratio in groundwater, less than $36 \mathrm{ng}$ of uranium is needed. This amount would be contained in about $10 \mathrm{~m} \ell$ of water from Yucca Mountain, which would contain $4 \mathrm{ppb}$ of uranium.

The case for thorium is not quite as clear because there are no data for Yucca Mountain. However, if the ${ }^{232} \mathrm{Th}$ concentration is about $0.01 \mathrm{ppb}$ and the ${ }^{230} \mathrm{Th} /{ }^{232} \mathrm{Th}$ ratio is close to $10^{-6}$, then a few liters of water would be sufficient to produce the 10 to $30 \mathrm{ng}$ of thorium we estimate is necessary for the analysis.

Because alpha spectroscopy appears to be readily applicable to both radon and radium, we have not considered the possibilities for determining these isotopes by mass spectrometry. 